\title{
Evaluation of the Influence of the Level of Corrosion of the Reinforcing Steel in the Moment-Curvature Diagrams of Rectangular Concrete Columns
}

\author{
Laura Landa-Ruiz, René Croche, Griselda Santiago-Hurtado, Victor Moreno-Landeros, \\ Josefina Cuevas, Ce Tochtli Méndez, Manuel Jara-Díaz, and Miguel Angel Baltazar-Zamora
}

\begin{abstract}
In the present work, it is proposed to include in the theoretical curves of moment-curvature (m- $\varphi)$ the effect of corrosion by obtaining the decrease in the area of longitudinal reinforcing steel. The corrosion depth will be obtained from the crack width and corrosion length observed in the cover concrete. With the depth of corrosion, the area of steel that is lost will be obtained and this modification will be incorporated into the theoretical procedure to elaborate the $m-\varphi$ curves. The forces of the steel will be obtained from an elastoplastic model with curved hardening and the forces of the concrete with a model that considers the effect of confinement.
\end{abstract}

Index Terms - Moment- Curvature; Corrosion; Crack; Column resistance.

\section{INTRODUCTION}

The modelling procedures of the plastic hinge of the elements of the reinforced concrete structures consider hypotheses of the behavior of the materials different from the hypotheses used for the design of the element, one of these hypotheses is based on modelling the stress-Strain curves of materials considering the effects of confinement and material deterioration, but current regulations only consider concrete deterioration due to cyclical loads and with these hypotheses, the moment-curvature diagrams that define the plastic hinge are constructed. Although these hypotheses can be used in cases where it is desired to evaluate a concrete structure or perform a non-linear analysis, they do not reflect the effect of the deterioration that the structure element may have due to carbonation of the concrete, due to loss of the section, due to cracking or corrosion of the steel of the reinforcing steel, which is the main cause of the deterioration of reinforced concrete structures, among the main aggressive agents are chloride ions, which according to the literature are considered the most aggressive [1]-[12], the sulfate ions are also considered as aggressive agents, which are present in wastewater, contaminated soils, groundwater, or industrial environments, so their effect on the corrosion of reinforcing steel and object has been of great interest. of diverse investigations with diverse proposals to mitigate the corrosion by sulphates [13]-[24], whose maintenance due to corrosion problems is billions of dollars in in the world [25][35], vey particularly in bridges of concrete due to the fact that they are reinforced concrete works of great repair cost and that the vast majority are in aggressive environments [36]-[46]. As mentioned in the previous paragraphs, to mitigate corrosion damage, various research works have been carried out, taking into account the quality of concrete, type of cement, additives, alternative materials to Portland cement, simulating aggressive contact media such as sulfates and chlorides, but most research is focused on mitigating the corrosion of reinforcing steel, and little information is available on the effect of corrosion or the level of corrosion present in important structures such as bridges and its effect on resistance to a seismic event. when they are already damaged by corrosion.

Therefore, the importance of the present work is considered, where the effect that the corrosion of the reinforcing steel has on the stress - strain graph of the concrete confined in rectangular columns was evaluated. The construction of the stress-strain curve of the concrete is done following the proposal of Mander [47], the stress-strain curve of steel with the values proposed by Mendoza [48] and in a first proposal, considering the loss of steel due to corrosion according to the criteria of Castonera [49].

\section{MATERIALS AND METHODS}

\section{A. Materials}

Normally the strengths of the materials, steel, and concrete, which are considered in a new project are conservative, for the modelling of the plastic hinge using the moment curvature diagrams values that reflect the real resistance of the material must be adopted. For this, in this work it is proposed to consider the forces of steel with an elastoplastic model with curved hardening and for the forces of concrete with a model that considers the effect of confinement.

Josefina Cuevas, Universidad Veracruzana, México.

(e-mail: jcrfauv@gmail.com)

Ce Tochtli Méndez, Universidad Veracruzana, México.

(e-mail: cmendez@ uv.mx)

Manuel Jara Díaz, UMISH, México.

(e-mail: mjarad10@gmail.com)

Miguel Angel Baltazar-Zamora, Universidad Veracruzana, México.

(e-mail: mbaltazar@uv.mx)

(e-mail: grey.shg@gmail.com)

Victor Moreno-Landeros, Universidad Autónoma de Coahuila, México.

(e-mail: vmmorlan@ gmail.com) 


\section{1) Strength of steel}

The stress-strain curve of steel will be modeled with the parameters proposed by Mendoza [48] and that incorporate the Complementary Technical Standards for Design and Construction of Concrete Structures (NTC, 2017) [50] in Table I.

TABLE I. PARAMETERS TO MODEL THE STRESS-STRAIN GRAPH OF THE REBAR

\begin{tabular}{ccc} 
& \multicolumn{2}{c}{ REBAR } \\
\hline \multirow{2}{*}{ Parameters } & \multicolumn{2}{c}{ Grado 42} \\
\cline { 2 - 3 } & $\mathrm{MPa}$ & $\mathrm{Kg} / \mathrm{cm}^{2}$ \\
\hline $\mathrm{f}_{\mathrm{y}}$ & 457 & 4487 \\
$\mathrm{f}_{\mathrm{su}}$ & 742 & 7280 \\
$\mathrm{f}_{\text {sh } 1}$ & 612 & 6000 \\
$\mathrm{E}_{\mathrm{s}}$ & 209218 & 2052433 \\
$\square_{\mathrm{y}}$ & \multicolumn{2}{c}{0.0022} \\
$\square_{\mathrm{sh}}$ & \multicolumn{2}{c}{0.0066} \\
$\square_{\mathrm{su}}$ & \multicolumn{2}{c}{0.1100} \\
$\square_{\mathrm{sh} 1}$ & \multicolumn{2}{c}{0.0248} \\
$\mathrm{~F}$ & \multicolumn{2}{c}{4.03} \\
\hline
\end{tabular}

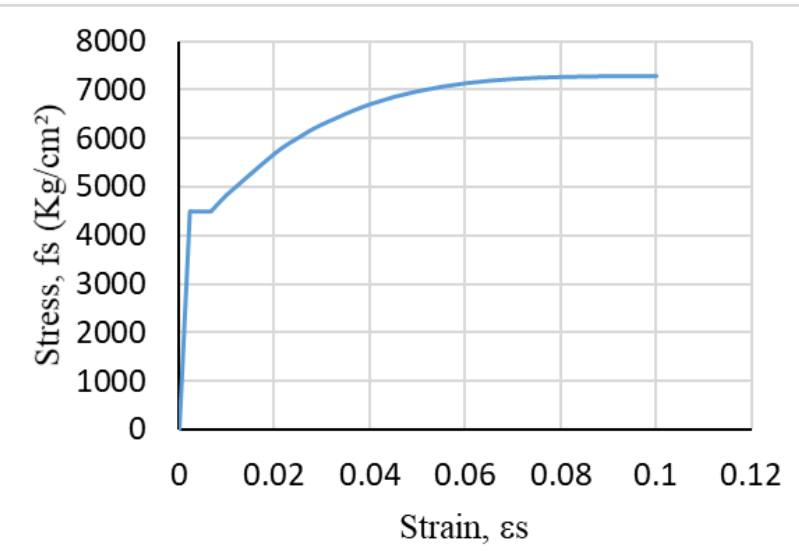

Fig. 1. Stress-Strain model of steel Gr. 42 incorporated in NTC (2017) [50].

\section{2) Strength of concrete}

The strength of the concrete considers the effect of the confinement provided by the transverse steel, for which the stress-strain curve is constructed in accordance with Fig. 2 [47], and which is a theoretical model accepted in current standards [50].

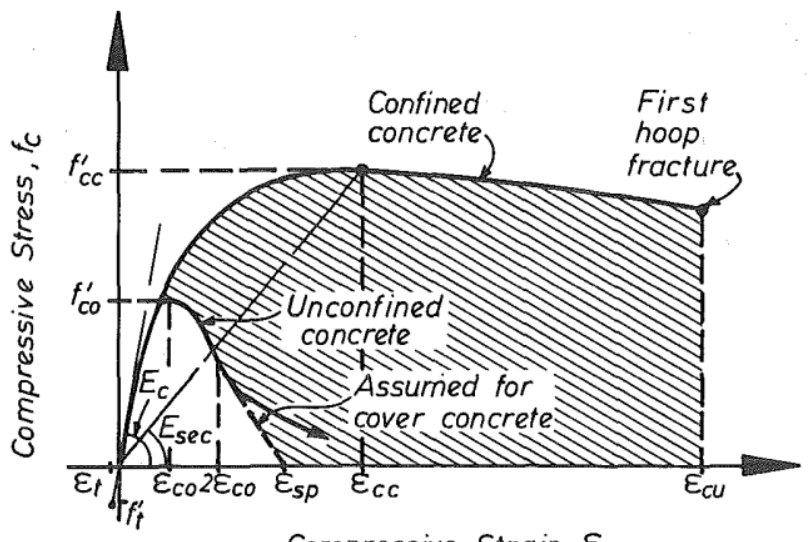

Compressive Strain, $\varepsilon_{C}$

Fig. 2. Stress-Strain model of confined and unconfined concrete [45]

In Fig. $2, f_{c o}^{\prime}$ is the compressive stress of simple concrete, commonly identified as $f_{c}^{\prime}, \varepsilon_{c o}$ is the unit strain of concrete when $f_{c o}^{\prime}$ is reached, which is considered $0.003, f_{c c}^{\prime}$ the maximum stress of compression considering the confinement and $\varepsilon_{c c}$ is the unit strain when it reaches said confinement. For rectangular sections the maximum stress $f_{c c}^{\prime}$ is obtained from the graph in Figure 3 that involves the confinement relationships $f_{l 1}^{\prime} / f_{c o}^{\prime}$ and $f_{l 2}^{\prime} / f_{c o}^{\prime}$.

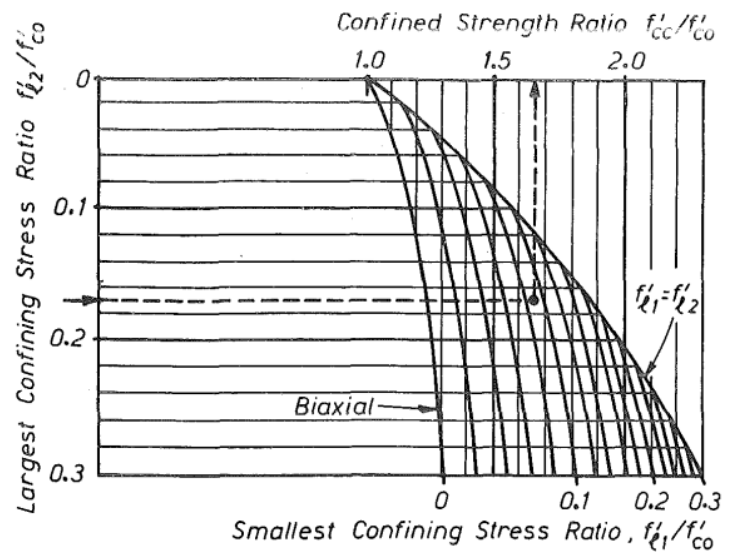

Fig. 3. Confined Strength determination from lateral confining stresses for rectangular sections [47].

$f_{l 1}^{\prime}$ and $f_{l 2}^{\prime}$ are the lowest and highest confining stress respectively in the $\mathrm{X}$ or $\mathrm{Y}$ direction obtained with (1) that depend on the percentages of longitudinal steel $\rho_{(x \text { o } y)}$ and an effective confinement factor $k_{e}$.

$$
f_{l(x o ́ y)}^{\prime}=k_{e} \rho_{(x o ́ n)} f_{y h}
$$

$k_{e}$ in turn, depends on the free spacing between the longitudinal bars $w_{i}^{\prime}$, free spacing between stirrups $s^{\prime}$, distance perpendicular to the direction $\mathrm{x} b_{c}$, distance perpendicular to the direction y $d_{c}$ and percentage of longitudinal steel $\rho_{c c}$. See Fig. 4.

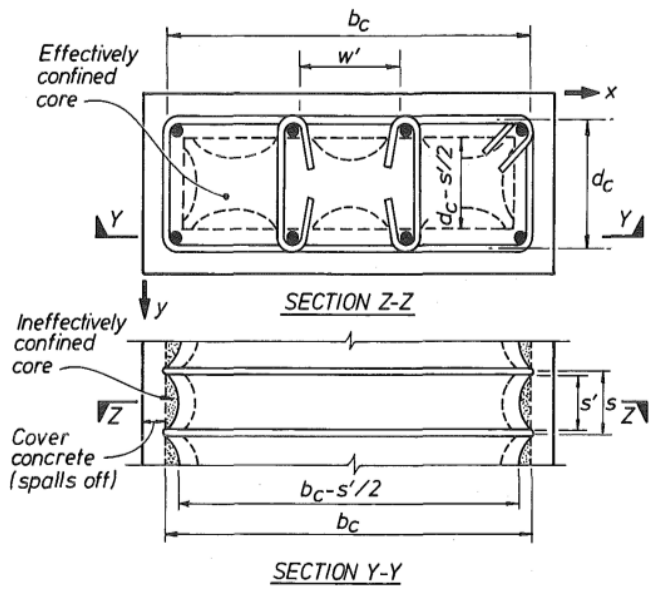

Fig. 4. Effectively confined core for rectangular hoop reinforcement [47].

To obtain the confinement effort $f_{c c}^{\prime}$, in a less visual way than when using the graph in Fig. 3 and allowing us to use a programmable spreadsheet, programmable equations were obtained which replace Fig. 3. Once the relations $f_{l 1}^{\prime} / f_{c o}^{\prime}$ and $\left.f_{l 2}^{\prime} / f_{c o}^{\prime}\right)$ two of the equations obtained are chosen and with the two results it is linearly interpolated to finally obtain the relation $f_{c c}^{\prime} / f_{c o}^{\prime}$. 


\section{B. Method}

\section{1) Ultimate deformation of concrete}

Some authors [51] recommend that the value adopted as the ultimate concrete deformation $\varepsilon_{c u}$ be 0.005 for the case of poorly confined concrete. For the case of well-confined concrete, the ultimate deformation can be obtained with (2) [52] derived from Mander's energy balance criterion, it also includes the deformation energy stored in the longitudinal reinforcement.

$$
\begin{aligned}
\varepsilon_{c u} & =\frac{110 \rho_{s}+3.4 \rho_{l}+0.017 \gamma \sqrt{f_{c}^{\prime}}}{\rho_{c c}\left(0.94 f_{y}+302\right)-\gamma\left(0.015 f_{c}^{\prime 2}-1.1 f_{c}^{\prime}-8\right)}\left(f_{c}^{\prime} y f_{y} \text { en MPa }\right) \\
\gamma & =0.45+0.5 \sqrt{\frac{P}{f_{c}^{\prime} A_{g}}}
\end{aligned}
$$

In (3) $\mathrm{P}$ is the axial force and $A_{g}$ is the thick section and the expression is only applicable for rectangular sections.

Fig. 5 shows the stress-strain curves for different concrete $f_{c}^{\prime}$ following the criteria established in section 2 of this document. The curves are specific for the section of the column of the same figure, which is reinforced with 8 rebars of the number 8 , hoop of the number 3 rod with a separation of $10 \mathrm{~cm}$
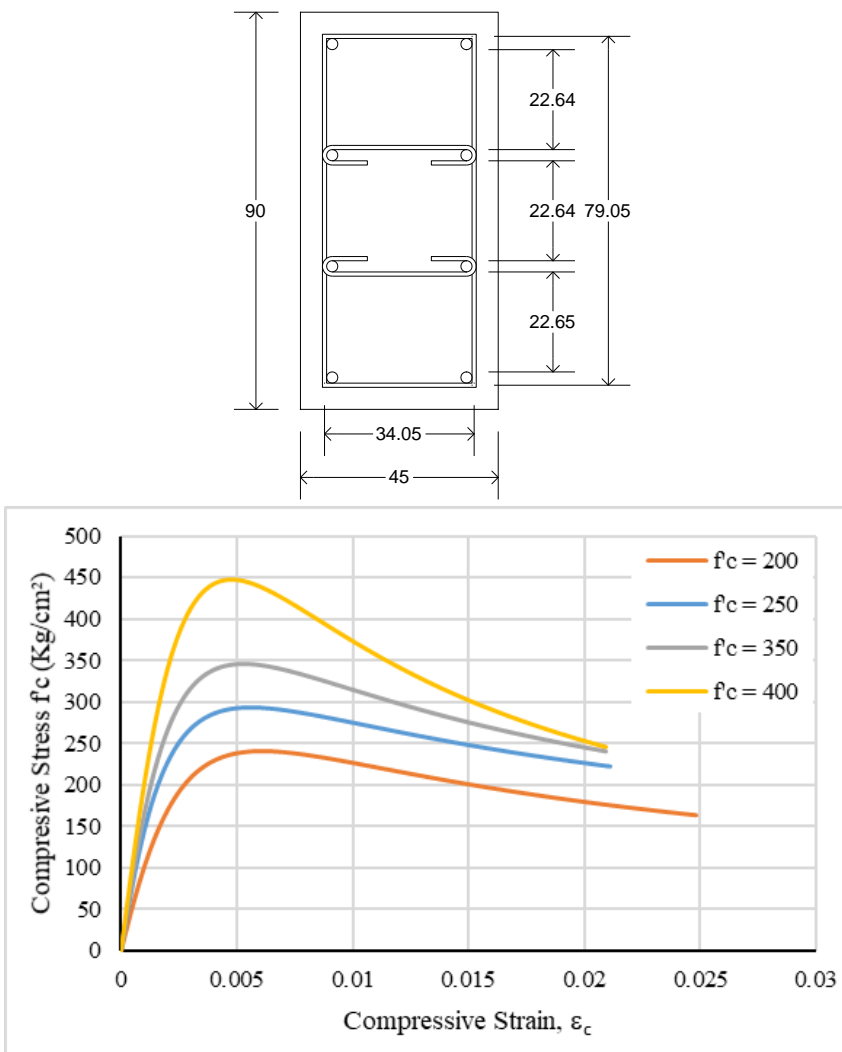

Fig. 5. Stress-Strain curves for the left column.

\section{2) Obtaining the moment-curvature diagrams $(M-\varphi)$}

Using our own code developed in the Visual Basic editor for Excel applications (VBA), the Moment - Curvature curves were calculated following the procedure described by some authors [53]-[54], with the variations that the ultimate deformation of the concrete will not be 0.005 as proposed, if not obtained with (2). The compressive strength of concrete $C_{c}$ is calculated with (4), where b is the base of the column section and $f^{\prime}{ }_{c c}$ is calculated with Mander's criterion.

$$
C_{c}=\propto f_{c c}^{\prime} b k d
$$

$\propto$ is a mean stress factor [54] can be calculated with (5), where the numerator represents the area under the concrete stress-strain curve, which in the VBA code is performed by increments of strain and $\gamma$, is the centroid factor for any strain $\varepsilon_{\mathrm{cm}}$.

$$
\begin{aligned}
& \propto=\frac{\int_{0}^{\varepsilon_{c} m} f_{c} d_{\varepsilon_{C}}}{f_{c c}^{\prime} \varepsilon_{c m}} \\
& \gamma=1-\frac{\int_{0}^{\varepsilon_{c}}{ }^{2} \varepsilon_{c} f_{c} d_{\varepsilon_{c}}}{\varepsilon_{c m} \int_{0}^{\varepsilon_{c m}} f_{c} d_{\varepsilon_{c}}}
\end{aligned}
$$

Following the procedure described, the diagram of Fig. 7 was obtained, for a value of $\mathrm{f}^{\prime} \mathrm{c}=250 \mathrm{~kg} / \mathrm{cm}^{2}$, the ultimate deformation $\varepsilon_{c u}$ calculated with formula (2) is 0.02145 .

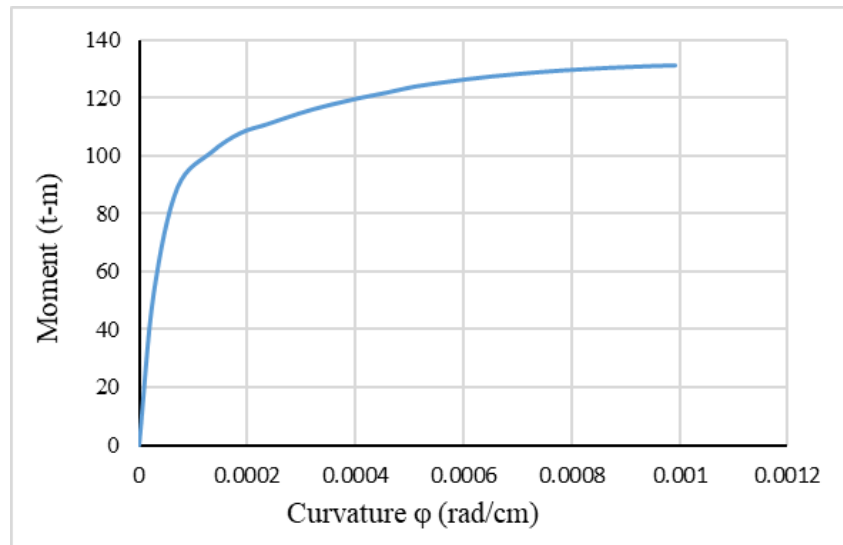

Fig. 7. Moment-Curvature curve for the column of Fig. 5.

\section{3) Corrosion damage}

The theoretical curves of moment - curvature (M- $\varphi$ ) are carried out under the hypotheses already established above but also under the assumption that the steel of the column is in optimal conditions, where it does not present cracking due to corrosion or decrease in the area of longitudinal steel due to corrosion. When it is desired to evaluate a concrete structure, the conservation conditions of the structure may not be optimal, the specific case of the columns of concrete bridges that are located in coastal cities or road sections near the sea show corrosion damage, due to which when making an evaluation in which it is necessary to have the M-pdiagram, would not be representing the real conditions of the concrete element.

Castorena [49] proposes a model to estimate the depth of corrosion of steel rods from the width of the corrosion crack, which can be measured by field inspection. The model involves only characteristics of the element, that is, the column and the mechanical properties of the concrete.

The model proposes that the corrosion depth $X_{\text {corr }}$ is given by the penetration on the steel at the moment of initiating the 
cracking of the cover concrete by corrosion $X_{o}$ plus the penetration in the steel after the first visible corrosion crack $X_{p}$ has appeared. See Fig. 8.

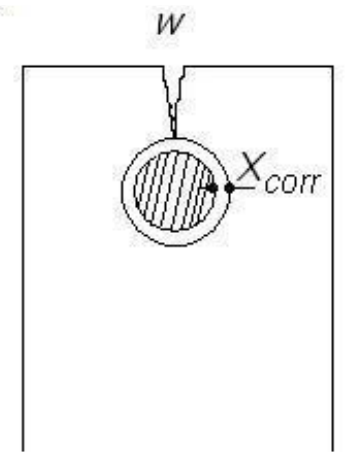

Fig. 8. Corrosion depth [49]

$$
X_{\text {corr }}=X_{o}+X_{p}
$$

\section{4) Penetration of corrosion at the beginning of the corrosion} cover concrete cracking $X_{o}$

The experimental results [49] show that the width of the first corrosion crack varies between 0.06 and 0.08 millimeters, which is when the initial corrosion penetration $X_{o}$ occurs and that we can estimate with (8). $X_{o}$ depends on C which is the value of the free coating that the steel has, $d$ the diameter of the rod and $\mathrm{L}$ anodic length, that is, the length of the corroded steel. These variables are shown in Fig. 9.

$$
X_{o}^{0.15}=0.4553\left(\frac{C}{d}\right)^{0.04} \delta^{-0.0653}\left(\frac{C}{L}\right)^{0.07}
$$

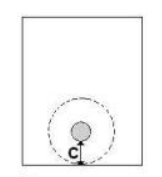

a)

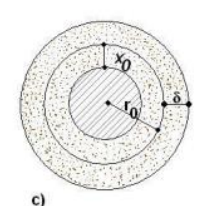

c)

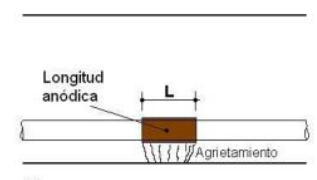

b)

d)

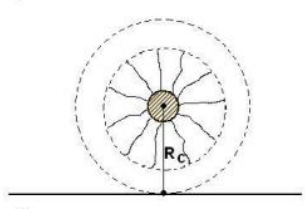

Fig. 9. Variables involved in the penetration of corrosion at the beginning of cracking [49].

It is recommended that the anode length can be fully identified using some appropriate electrochemical technique.

The parameter $\delta$ is a function of the radius of the rod $r_{o}$, the poisson's moduli of concrete and steel respectively $v_{c}$ and $v_{a}$, the modulus of elasticity of steel and concrete $E_{a}$ and $E_{c}$ and of $R_{c}$ which is equal to the sum of the radius of the rod plus the free cover concrete as indicated in Fig. 9 d). $\delta$ is obtained with (9) and represents the oxide layer necessary to produce tangential forces equal to the maximum tensile strength of the concrete and initiate cracking at the steel-concrete interface.

$$
\delta=2 r_{o} P_{g}\left[\frac{1-v_{a}}{E_{a}}+\frac{\left(1+v_{c}\right) R_{C}^{2}+\left(1-v_{c}\right) r_{o}^{2}}{E_{c}\left(R_{c}^{2}-r_{o}^{2}\right)}\right]
$$

$P_{g}$ is the radial pressure at the steel-concrete interface and is obtained with equation (10), where $f_{t}$ is the concrete tensile stress and for our study it is calculated as established by the NTC (2017) based on the type of concrete being used.

$$
P_{g}=\frac{f_{t}}{\left[\frac{R_{c}^{2}+r_{o}^{2}}{R_{c}^{2}-r_{o}^{2}}+v_{c}\right]}
$$

If we set the values of the corrosion length to $150 \mathrm{~mm}$ and the free cover of $50 \mathrm{~mm}$, we can see in Figure 10 how the diameter of the rod and the concrete resistance influence the initial corrosion penetration $\boldsymbol{X}_{\boldsymbol{o}}$. The rods of smaller diameter and the concretes of smaller resistance are those that present higher values of length of initial corrosion and for concretes with value of f'c greater than $290 \mathrm{~kg} / \mathrm{cm}^{2}$ the stress of the concrete is no longer a variable that affects the value of $\boldsymbol{X}_{\boldsymbol{o}}$.

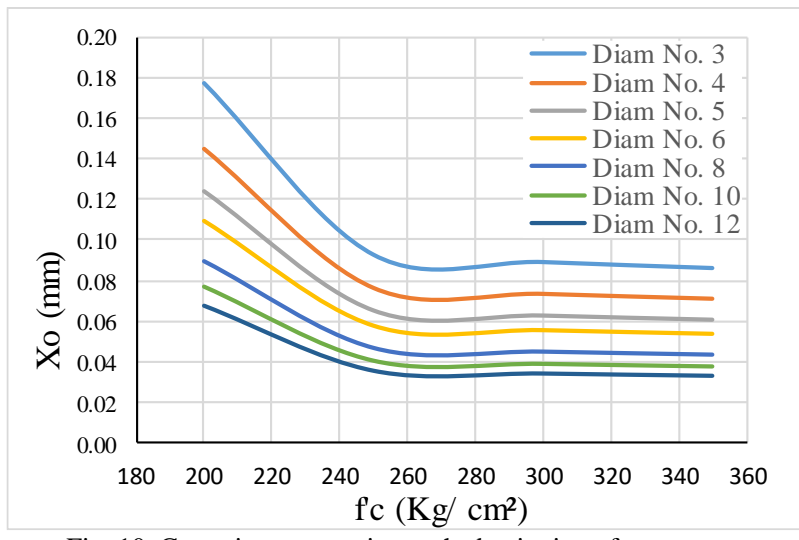

Fig. 10. Corrosion penetration at the beginning of cover concrete cracking for different values of $\mathrm{f}^{\prime} \mathrm{c}$ and different diameters of the steel.

\section{5) Corrosion penetration after first visible corrosion crack appeared $X_{p}$}

After the appearance of the first corrosion crack in the cover concrete, the reduction in radius continues to depend on the crack width $\mathrm{w}$ and can be calculated with the formula (11) proposed by Castorena [49]. In figure 11 we can see the variation of $X_{p}$ for different crack widths.

$$
X_{p}^{0.20}=-1.3565+1.8673 w^{0.08634}
$$

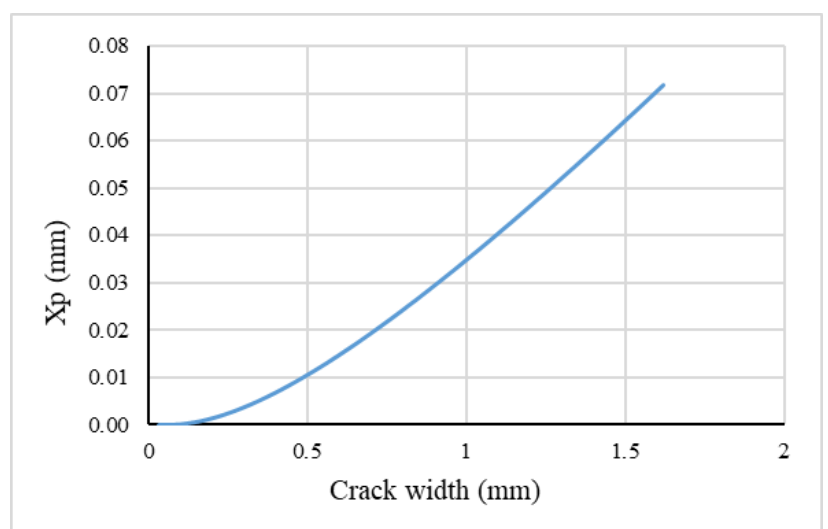

Fig. 11. Corrosion penetration after the first corrosion crack appeared. 


\section{RESULTS AND DISCUSSION}

In research carried out [55] there is a notable difference in the crack width of the different sides of the section (front section and rear section) of specimens exposed to marine environments, this mainly due to the fact that exposure to the aggressive agents is different in the structural elements depending on their orientation, this can be seen in Fig. 12, the concrete elements present greater corrosion damage on one of the faces.

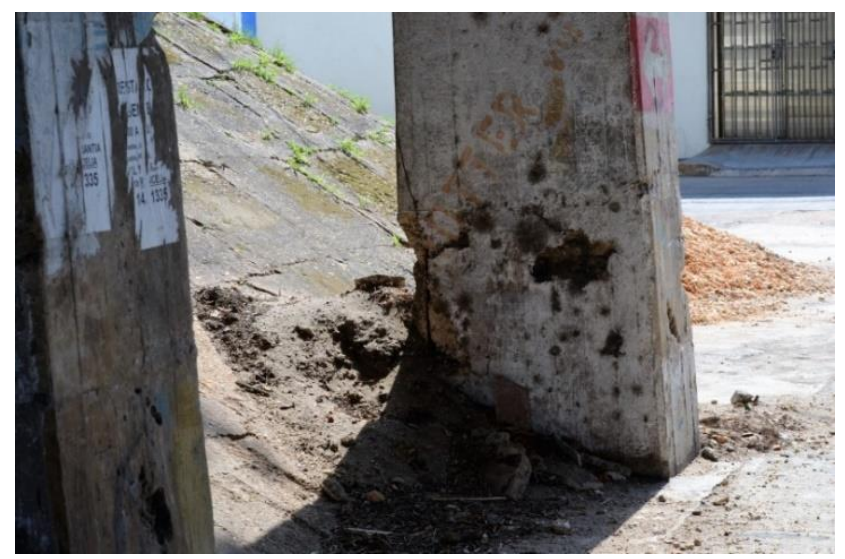

Fig. 12. Column of the Palma Sola bridge located in Coatzacoalcos, Veracruz, México.

Applying the criteria set out above, assuming a corrosion length of $100 \mathrm{~mm}$, an $\mathrm{f}^{\prime} \mathrm{c}=250 \mathrm{~kg} / \mathrm{cm}^{2}$, different crack widths and a cross section of the dimensions of Fig. 5, with rebars of number 8 , stirrups of the number 3 at a separation of $10 \mathrm{~cm}$, we obtain Fig. 13.

In Fig. 13, the curve for $\mathrm{w}=0$ corresponds to the section of Fig. 5, considering that the steel has not suffered corrosion damage, the other three curves shown in Fig. 5 are considering that the longitudinal steel in only one of the faces already show corrosion damage and this is estimated according to the width of the crack, in this case, crack widths of $0.06 \mathrm{~mm}, 1 \mathrm{~mm}$ and $1.5 \mathrm{~mm}$ were assumed. When the first corrosion crack appears in the cover concrete of an approximate width of $0.06 \mathrm{~mm}$, the depth of the corrosion is a distance of $0.05288 \mathrm{~mm}$ and corresponds only to $X_{O}$.

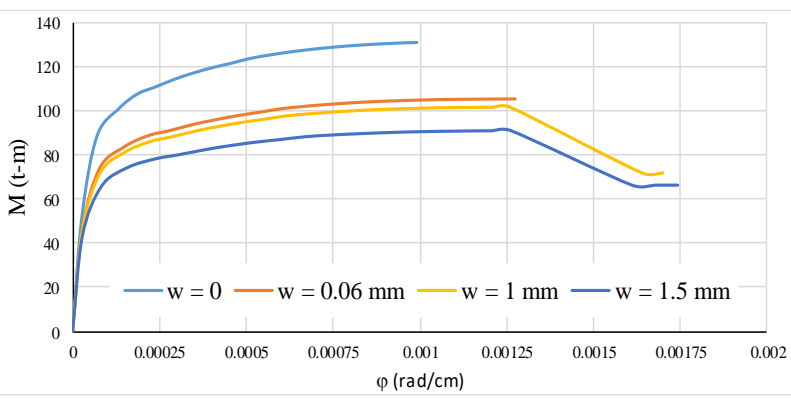

Fig. 13. Moment - Curvature curve for the rectangular column damaged by corrosion.

TABLE II: CORROSION DEPTH FOR DIFFERENT CRACK THICKNESSES FROM THE SECTION OF FIG. 5

\begin{tabular}{ccccc}
\hline $\mathrm{W}(\mathrm{mm})$ & $\mathrm{X}_{\mathrm{p}}(\mathrm{mm})$ & $\mathrm{X}_{\mathrm{o}}(\mathrm{mm})$ & $\mathrm{X}_{\text {corr }}(\mathrm{mm})$ & \% Lost steel area \\
\hline 0.06 & 0.0000 & 0.0529 & 0.0529 & 65.97 \\
1 & 0.0348 & 0.0529 & 0.0877 & 90.40 \\
1.5 & 0.0641 & 0.0529 & 0.1170 & 99.38 \\
\hline
\end{tabular}

In Fig. 13 we see how the M- $\varphi$ diagram is affected by the corrosion damage that the element may present. The greatest decrease in moment occurs when the first crack appears, reducing the maximum moment by approximately $20 \%$. We can also observe that the ultimate curvature increases as the crack width increases, despite the fact that the percentage of steel loss per affected rod is of the order of $90 \%$ (See Table II) for larger crack widths.

\section{CONCLUSIONS}

In a process of evaluation of concrete structures through a non-linear analysis where the moment-curvature diagrams are required for the modelling of the plastic hinges, the theoretical approaches that represent the real conditions of the element, in terms of materials and conservation of the structure.

It is feasible to use Castorena's proposal to estimate the reduction of steel radius due to corrosion, since his proposal only requires the observation on site of the crack width, elementary data of the geometry and information and materials of the concrete section.

Including the corrosion damage of the moment-curvature diagrams describes a better behavior of the element, especially for evaluation purposes, since the element can theoretically present a decrease of $20 \%$ of the moment when the first crack appears compared to what moment it would reach if the section did not show corrosion.

\section{ACKNOWLEDGMENT}

MA Baltazar-Zamora, et. al., thank PRODEP for the support granted by the SEP, the Academicians UV-CA-458 "Sustainability and Durability of Materials for Civil Infrastructure" under the Call 2018 for Strengthening Academic Bodies with IDCA 28593. The authors thank A. Landa-Sanchez for the technical support.

\section{REFERENCES}

[1] G. Cosoli, A. Mobili, N. Giulietti, P. Chiariotti, G. Pandarese, F. Tittarelli, T. Bellezze, N. Mikanovic, G.M. Revel. (2020). Performance of concretes manufactured with newly developed low-clinker cements exposed to water and chlorides: Characterization by means of electrical impedance measurements. Construction and Building Materials. 271 121546.

[2] Miguel Angel Baltazar-Zamora, José Manuel Mendoza-Rangel, René Croche, Citlalli Gaona-Tiburcio, Cindy Hernández, Luis López, Francisco Olguín, Facundo Almeraya-Calderón. (2019). Corrosion Behavior of Galvanized Steel Embedded in Concrete Exposed to Soil Type MH Contaminated with Chlorides. Frontiers in Materials, 6, pp. $1-12$.

[3] C. Pan, X. Li, J. Mao. (2020). The effect of a corrosion inhibitor on the rehabilitation of reinforced concrete containing sea sand and seawater. Materials. 13, 1480.

[4] G. Santiago-Hurtado et. al. (2016). Electrochemical Evaluation of a Stainless Steel as Reinforcement in Sustainable Concrete Exposed to Chlorides. International Journal of Electrochemical Science, 11:4, pp. 2994-3006.

[5] H.A.F. Dehwah, M. Maslehuddin, S.A. Austin. (2002). Long-term effect of sulfate ions and associated cation type on chloride-induced reinforcement corrosion in Portland cement concretes. Cement and Concrete Composites. 24, pp. 17-25.

[6] M.A. Baltazar-Zamora et. al. (2012). Efficiency of Galvanized Steel Embedded in Concrete Previously Contaminated with 2, 3 and $4 \%$ of 
$\mathrm{NaCl}$. International Journal of Electrochemical Science, 7:4, pp. $2997-$ 3007.

[7] S.R. Yeomans. (1994). Performance of Black, Galvanized, and EpoxyCoated Reinforcing Steels in Chloride- Contaminated Concrete. Corrosion. 50, pp.72-81.

[8] M.A. Baltazar-Zamora, D.M. Bastidas, G. Santiago-Hurtado, J.M. Mendoza-Rangel, C. Gaona-Tiburcio, J.M. Bastidas, F. AlmerayaCalderón. (2019). Effect of Silica Fume and Fly Ash Admixtures on the Corrosion Behavior of AISI 304 Embedded in Concrete Exposed in 3.5\% NaCl Solution. Materials (Basel), 12:23, pp. 1-13.

[9] F. Shaheen, B. Pradhan. (2017). Influence of sulfate ion and associated cation type on steel reinforcement corrosion in concrete powder aqueous solution in the presence of chloride ions. Cement and Concrete Research. 91, pp. 73-86.

[10] Miguel Angel Baltazar-Zamora, Abigail Landa-Sánchez, Laura LandaRuiz, Hilda Ariza-Figueroa, Pedro Gallego-Quintana, Aldo RamírezGarcía, René Croche, Sabino Márquez-Montero. (2020). Corrosion of AISI 316 Stainless Steel Embedded in Sustainable Concrete made with Sugar Cane Bagasse Ash (SCBA) Exposed to Marine Environment. European Journal of Engineering Research and Science, 5:2, pp. 127 131.

[11] G. Roventi, T. Bellezze, G. Giuliani, C. Conti. (2014) Corrosion resistance of galvanized steel reinforcements in carbonated concrete: Effect of wet-dry cycles in tap water and in chloride solution on the passivating layer. Cement and Concrete Research. 65, pp. 76-84.

[12] M.A. Baltazar-Zamora, G. Santiago-Hurtado, V.M. Moreno L, R. Croche B, M. de la Garza, F. Estupiñan L, P. Zambrano R., C. GaonaTiburcio. (2016). Electrochemical Behaviour of Galvanized Steel Embedded in Concrete Exposed to Sand Contaminated with $\mathrm{NaCl}$ International Journal of Electrochemical Science, 11:12, pp. 10306 10319.

[13] D. Wang, X. Zhao, Y. Meng, Z. Chen. (2017). Durability of concrete containing fly ash and silica fume against combined freezing-thawing and sulfate attack. Construction and Building Materials. 147, pp. 398 406

[14] M.A. Baltazar-Zamora, G. Santiago-Hurtado, C. Gaona-Tiburcio et. al (2012). Evaluation of the corrosion at early age in reinforced concrete exposed to sulfates. International Journal of Electrochemical Science, 7:1, pp. 588-600

[15] V.V. Praveen, D. Ravi. (2019). Influence of supplementary cementitious materials on strengthand durability characteristics of concrete. Advanced in Concrete Construction. 7, pp. 75-85.

[16] G. Santiago-Hurtado et. al. (2016). Electrochemical Evaluation of Reinforcement Concrete Exposed to Soil Type SP Contaminated with Sulphates. International Journal of Electrochemical Science, 11:6, pp. 4850-4864.

[17] G. Burtuujin, D. Son, I. Jang, C. Yi, H. Lee. (2020). Corrosion behavior of pre-rusted rebars in cement mortar exposed to harsh environment. Applied Sciences. 10, 8705.

[18] Abigail Landa-Sánchez et. al. (2020). Corrosion Behavior of SteelReinforced Green Concrete Containing Recycled Coarse Aggregate Additions in Sulfate Media. Materials (Basel), 13:19, pp. 1-22.

[19] M.L. Berndt. (2009). Properties of sustainable concrete containing fly ash, slag and recycled concrete aggregate. Construction and Building Materials, 23:7, pp. 2606-2613.

[20] Hilda A. Ariza-Figueroa et. al. (2020). Corrosion Behavior of AISI 304 Stainless Steel Reinforcements in SCBA-SF Ternary Ecologica Concrete Exposed to $\mathrm{MgSO}_{4}$. Materials (Basel), 13:10, pp. 1-16.

[21] P. Xu, L. Jiang, M. Guo, J. Zha, L. Chen, C. Chen, N. Xu. (2019) Influence of sulfate salt type on passive film of steel in simulated concrete pore solution. Construction and Building Materials. 223, pp. 352-359.

[22] Miguel Angel Baltazar-Zamora, Hilda Ariza-Figueroa, Laura LandaRuiz, and René Croche. (2020). Electrochemical Evaluation of AISI 304 SS and Galvanized Steel in Ternary Ecological Concrete based on Sugar Cane Bagasse Ash and Silica Fume (SCBA-SF) exposed to $\mathrm{Na}_{2} \mathrm{SO}_{4}$. European Journal of Engineering Research and Science, 5:3, pp. 353-357.

[23] B. Pradhan. (2014). Corrosion behavior of steel reinforcement in concrete exposed to composite chloride-sulfate environment. Construction and Building Materials. 72, pp. 398-410.

[24] Laura Landa-Ruiz et. al. (2021). Electrochemical Corrosion of Galvanized Steel in Binary Sustainable Concrete Made with Suga Cane Bagasse Ash (SCBA) and Silica Fume (SF) Exposed to Sulfates. Applied Sciences. 11, 2133.

[25] M. Ormellese, M. Berra, F. Bolzoni, T. Pastore. Corrosion inhibitor for chlorides induced corrosion in reinforced concrete structures. Cement and Concrete Research. 36, pp. 536-547.

[26] V. Volpi-León, L.D. López-Léon, J. Hernández-Ávila, M.A. BaltazarZamora, F.J. Olguín-Coca, A.L. López-León. (2017). Corrosion study in reinforced concrete made with mine waste as mineral additive International Journal of Electrochemical Science, 12:1, pp. 22-31.

[27] W. Raczkiewicz, A. Wójcicki. (2020). Temperature Impact on the Assessment of Reinforcement Corrosion Risk in Concrete by Galvanostatic Pulse Method. Applied Sciences. 10, 1089.

[28] Miguel Angel Baltazar-Zamora, Sabino Márquez-Montero, Laura Landa-Ruiz, René Croche, Oscar López-Yza. (2020). Effect of the type of curing on the corrosion behavior of concrete exposed to urban and marine environment. European Journal of Engineering Research and Science, 5:1, pp. 91-95.

[29] R. E. Melchers, C.Q. Li. (2009). Reinforcement corrosion initiation and activation times in concrete structures exposed to severe marine environments. Cement and Concrete Research. 39, pp. 1068-1076.

[30] O. Troconis de Rincón et. al., (2016). Reinforced Concrete Durability in Marine Environments DURACON Project: Long-Term Exposure. Corrosion, 72:6, pp. 824-833.

[31] G. Cosoli, A. Mobili, F. Tittarelli, G.M. Revel, P. Chiariotti. (2020) Electrical Resistivity and Electrical Impedance Measurement in Mortar and Concrete Elements: A Systematic Review. Applied Sciences. 10 9152.

[32] G. Santiago-Hurtado et. al. (2012). Electrochemical Behavior of Reinforced Concrete and Its Relation with the Environment of Xalapa, Veracruz. International Journal of Electrochemical Science, 7:10, pp. 9825-9834.

[33] M.T. Liang, J.J. Lan. (2005). Reliability analysis for the existing reinforced concrete pile corrosion of bridge substructure. Cement and Concrete Research. 35, pp. 540-550.

[34] Laura Landa-Ruiz, Sabino Márquez-Montero, Griselda SantiagoHurtado, Victor Moreno-Landeros, José Manuel Mendoza-Rangel, and Miguel Angel Baltazar-Zamora. (2021). Effect of the Addition of Sugar Cane Bagasse Ash on the Compaction Properties of a Granular Materia Type Hydraulic Base. European Journal of Engineering and Technology Research, 6:1, pp. 76-79.

[35] O. Ojeda-Farías, J.M. Mendoza-Rangel, M.A. Baltazar-Zamora (2018). Influence of sugar cane bagasse ash inclusion on compacting, CBR and unconfined compressive strength of a subgrade granular material. Revista ALCONPAT, 8:2, pp. 194-208.

[36] S.D. Cramer, B.S. Covino, S.J. Bullard, G.R. Holcomb, J.H. Russell, F.J. Nelson, H.M. Laylor, S, M. Soltesz. (2002). Corrosion prevention and remediation strategies for reinforced concrete coastal bridge Cement and Concrete Composites. 24, pp. 101-117.

[37] Laura Landa-Ruiz, Hilda Ariza-Figueroa, Griselda Santiago-Hurtado, Victor Moreno-Landeros, Raul López Meraz, Rafael Villegas-Apaez, Sabino Márquez-Montero, René Croche, Miguel Angel BaltazarZamora. (2020). Evaluation of the Behavior of The Physical and Mechanical Properties of Green Concrete Exposed to Magnesium Sulfate. European Journal of Engineering Research and Science, 5:11, pp. 1353-1356.

[38] R.B. Figueira. (2017). Electrochemical sensors for monitoring the corrosion conditions of reinforced concrete structures: A review. Applied Sciences. 7, 1157.

[39] Miguel Angel Baltazar-Zamora, Laura Landa-Ruiz, Yazmin Rivera, René Croche. (2020). Electrochemical Evaluation of Galvanized Stee and AISI 1018 as Reinforcement in a Soil Type MH. European Journal of Engineering Research and Science, 5:3, pp. 259-263.

[40] V. Farhangi, M. Karakouzian. (2020). Effect of fiber reinforced polymer tubes filled with recycled materials and concrete on structural capacity of pile foundations. Applied Sciences. 10, 1554.

[41] G. Santiago-Hurtado, M.A. Baltazar-Zamora, A. Galindo D, J.A Cabral M, F.H. Estupiñán L., P. Zambrano Robledo, C. GaonaTiburcio. (2013). Anticorrosive Efficiency of Primer Applied in Carbon Steel AISI 1018 as Reinforcement in a Soil Type MH. International Journal of Electrochemical Science, 8:6, pp. 8490-8501.

[42] C.P. Barrios Durstewitz, F.J. Baldenebro López, R.E. Núñez Jaquez, G. Fajardo, F. Almeraya, E. Maldonado-Bandala, M. Baltazar-Zamora J.H. Castorena. (2012). Cement Based Anode in the Electrochemica Realkalisation of Carbonated Concrete. International Journal of Electrochemical Science, 7:4, pp. 3178 - 3190.

[43] A. Landa-Gómez et.al., (2018). Corrosion Behavior 304 and 316 Stainless Steel as Reinforcement in Sustainable Concrete Based on Sugar Cane Bagasse Ash Exposed to $\mathrm{Na}_{2} \mathrm{SO}_{4}$. ECS Transactions. 84 pp. $179-188$

[44] W. Raczkiewicz, P.G. Kossakowski. (2019). Electrochemical diagnostics of sprayed fiber-reinforced concrete corrosion. Applied Sciences. 9, 3763

[45] A. Landa-Gómez et.al., (2018). Correlation of Compression Resistance and Rupture Module of a Concrete of Ratio w/c $=0.50$ with the Corrosion Potential, Electrical Resistivity and Ultrasonic Pulse Speed ECS Transactions. 84, 217-227. 
[46] M. Baltazar, F. Almeraya, D. Nieves, A. Borunda, E. Maldonado, A Ortiz. (2007). Corrosión del acero inoxidable 304 como refuerzo en concreto expuesto a cloruros y sulfatos. Scientia Et Technica, 13:36, pp. 353-357.

[47] J.B. Mander, M.J.N. Priestley, R. Park. (1988). Theoretical StressStrain model for confined concrete. Journal of Structural Engineering. 114, pp. 1804-1826.

[48] C.J. Mendoza, C. Aire, J. López, F. Hernández. (2013), Propiedades mecánicas de barras de refuerzo grados 4, 52 y 56 . Instituto de Ingeniería, UNAM.

[49] J. Castorena. (2007). Daño por corrosión en estructuras de concreto reforzado a partir del ancho de grieta. Tesis Doctoral. Centro de Investigación en Materiales Avanzados, Chihuahua, México, pp. 100.

[50] Normas Técnicas Complementarias para el Diseño y Construcción de Estructuras de Concreto. (2017). Gaceta Oficial de la Ciudad de México. México, México.

[51] M. J. N., Priestley, F. Seible, G.M. Calvi. (1996). Seismic Design and Retrofit of Bridges. A Wiley-Interscience Publication. Jonh Wiley \& Sons, Inc. Nueva Jersey, U.S.A.

[52] M. Jara. (2004). Procedimiento de diseño sísmico basado en desplazamientos, para puentes con aisladores de base histeréticos. Tesis Doctoral, Universidad Politécnica de Cataluña, Barcelona España. pp. 149.

[53] A. H. Nilson. (1997). Design of Concrete Structures. McGraw-Hill Companies, U.S.A.

[54] R. Park, T. Paulay. (1980). Estructuras de Concreto Reforzado. Editorial Limusa, México, México.

[55] T. Vidal, A. Castel, R. Francois, R. (2004). Analyzing crack width to predict corrosion in reinforced concrete. Cement and Concrete Composites. 22, pp. 407-415. 